\title{
TRANSITION INTO HIGHER EDUCATION: THE STRUCTURE AND PRACTICE OF ACADEMIC ADVISING
}

\author{
Vafa Yunusova \\ Assistant Prof. Dr., ADA University, Azerbaijan, vyunusova@ada.edu.az
}

\begin{abstract}
This article aims to understand how four-year public institutions in the U.S. assist students in transitioning into higher education (HE) and how the individual characteristics and qualifications of academic advisors and administrators contribute to first-year students' transition and navigation through the campus.

As higher education comprises not only direct instruction facilitated by the faculty, teaching is also employed in academic staff's and academic advisor's responsibilities (Crookston, 1972; Hunter \& White, 2004). Hence, Appleby (2008) considers advising as teaching. Academic advisors explore their interests, weaknesses and strengths, and the impact of classes students favor, directing students to resources on campus and encouraging their socialization. Conversing about ethics, beliefs and values, academic advisors help students align their academic engagement and socialization (Bigger, 2005; Campbell, 2008).

The study based on educational inquiry (Maxwell, 2013) drives primarily on interviews (Kvale, 2006). The constructivist and interpretivist frameworks are interchangeably applied. The collected, analyzed, and interpreted data facilitate understanding of the organization and delivery of academic advising in a four-year public institution in the U.S..
\end{abstract}

A purposeful sampling, particularly snowball sampling strategy, has been utilized. The saturation applied has helped to find distinct knowledgeable individuals. Data triangulation has assisted in drawing the evidence from multiple sources, including observation and document review. The construct validity and reliability of findings have been addressed and established.

The findings do not reveal any fixed or long-established guideline for advising first-year students, except Academic Orientation Programs in fall, spring, and summer terms and First-year seminars. This research has occurred right in the middle of a year of significant change in advising at a college level. Loosely coordinated and decentralized advising practice in the College of IT, Technology, and Machinery has transitioned and moved under the Undergraduate Studies Office. The big shift in the structure has made academic advising delivery somewhat consistent, centrally coordinated, and overseen across the campus.

The academic advisors and supervisors' evaluation and assessment of advising delivery is not completely centralized and unified across campus. Neither fixed nor established benchmarks are available. The evaluation forms and templates differ from college to college, even departments. A new rewarding component has been incorporated into the assessment process. The leadership tends to conduct centralized student surveys and uses analyzed data as the base for changes by a taskforce. Thus, the departments individually launch students survey to measure student satisfaction on academic advisors' performance. The leadership attempts to align professional development activities, training programs and delivery of advising with NACADA core competency areas. A brand-new Advisor Portal fosters fast and constant virtual interaction and communication across campus community. However, networking is not effectively used as expected. 
Based on the Academic Advising Model utilized in the research site, the researcher offers an adapted academic advising model to be established as a structure in HEls in the Republic of Azerbaijan. The Academic Advising Model is a combination of academic services and student affairs, which is a centralized advising unit in which professional academic advisors and faculty are housed in one office. The centralized model may assist HEls in the Republic of Azerbaijan to best ensure the first-year students have equal access to quality studies and academically support them.

Keywords: higher education, academic advising, advising model

\section{INTRODUCTION}

Academic advising has been placed at the center of student achievement in four-year public institutions in the U.S.. Given the importance of academic advising, research consistently highlights its great significance for students' personal, academic, and social lives. Light (2001) states, "It is hard to imagine any academic support function that is more important to student success and institutional productivity than advising" (p. 81), because advising services in HE assist first-year students to choose courses and appropriately schedule them, help select a major, and plan a future career. In this respect, the academic advisors' impact on the first-year students' social integrations (Robbins et al., 2009) and retention (Gordon et al., 2011) in higher education is essential.

Gordon et al. (2011) assert that if the advising programs succeed, they not only positively influence students' retention but also increase the number of graduates, which entails graduates' educational and career goals achievement. Uhlik (2004) emphasizes positive influence of academic advising on students' persistence, skill acquisition and development, students' aspirations, and their satisfaction with both academic and career decisions. Similarly, Tinto (2006) stresses the importance of academic advising that provides a "road map to completion" (p. 2) and how academically supported students gain clarity of expectations and readiness in achieving personal and career goals.

Unlike four-year public institutions in the U.S., the higher education institutions (HEIs) in the Republic of Azerbaijan do not provide students with academic advising, and a pivotal component is missing in the higher education culture (Light, 2001). As faculty advisors only advise graduates, academic advising remains fragmented. Such mediocracy exits because the higher education system is centralized, the organizational structure is highly hierarchical, and the educational leadership executed is traditionally based on the topdown authority (Boer et al., 2017).

\subsection{Definition}

The overall aims of academic advising as a social institution are to promote the students' self-exploration, self-awareness, and self-evaluation; to assist students in recognizing the value of successes and also failures; to help students to explore choices and make reasonable choices according to interests, skills and abilities; and to sustain "the centrality of the academic curriculum" (Hemwall \& Trachte, 1999, p. 7). The advising institution considers the students' values, beliefs, aspirations, goals, and interests and helps to construct knowledge, synthesize the knowledge learned, and apply the knowledge by means of developed skills. Such social and academic capital contextualizes the students' everyday life, social, and academic experiences.

O'Banion $(1972,2013)$ highlights, "Academic advising is the second most important function in the college," and defines as "a process in which advisor and advisee enter a dynamic relationship respectful of the student's concerns" (2013, p.3). This assertion implies that an advisor and an advisee interact as partners. The advisor takes the role of a teacher, guides the student, and assists in responding to his concerns.

Similarly, Noel-Levitz (1997) defines advising as "a process of giving students guidance, support and encouragement"(p.3), whilst Grites (1979) asserts that advising is "a decision-making process during which students realize their maximum educational potential through communication and information exchanges with an advisor" (p.1).The social interaction and partnership that occur during the advising process may increase student expectations, and the students become more conscious about their potential, strengths, and weaknesses. Becoming more conscious about their own potential, strengths, and weaknesses triggers students' minds and develops more self-awareness. Noel-Levitz (1997) argues that this advanced selfawareness is "helping students diminish the confusion that comes with a new environment, clarify their 
goals, and get the most out of their education" (p.3). As a result, student performance may be positively impacted by advising.

Grites, Noel-Levitz, and O'Banion while defining advising, stress process as an important component. In other words, academic advising does not mean a simple action, one meeting, or one event. It goes beyond this simplicity and embeds a series of fixed, routinized procedures, actions, meetings, and events that occur in the course of bounded time (e.g., one semester, a year, two or four years, etc.), generally between two individuals when they converse and share.

When the researchers define an academic advisor, they relate academic advising to teaching and learning process when advisors contribute to students' understanding of the curriculum, constructing meanings and connecting them, fastening their academic, career, and life goals, and learning and developing as a whole (Hemwall \& Trachte, 2005; Lowenstein, 2005, 2013; Smith \& Allen, 2006, 2008). Undoubtedly, the academic advisor plays a significant role in transfer students' and freshmen's social and educational lives because advising as an intellectual process concentrates on teaching and learning and integrating each student's curriculum. Consequently, the curriculum is highlighted as it encompasses a well- designed, planned program of identified objectives, required courses based on various subjects, academic content, skills and experiences that lead the students to accomplishment. In regard to a well-designed program and student accomplishment, Hagen and Jordan (2008) consider advisors as academics who can teach curriculum, assist students in understanding and relating curriculum to their personal, social, and academic lives, and help students become lifelong learners.

\subsubsection{Problem Statement}

Over the past decades, concerns related to college transition and students' psychological, personal, social, and academic lives have triggered the evolution of academic advising as a profession in colleges and research universities in the US. The evolution of the profession has established structures such as academic services and student affairs in those education entities, although Bailey et al. (2015) highlight the "current organizational structures, hierarchies, and cultures are too powerful and well entrenched to be threatened by abstractions, no matter how ambitious" (Bailey et al., 2015, p. 12).

A survey conducted among more than 225, 000 undergraduates in over 425 US higher education institutions has revealed that academic advising is the second most important component of student's college experience after the quality of instruction (Hale, Graham, \& Johnson, 2009). Previous researchers discovered that in $947 \mathrm{HEIs}$ (Higher Education Institutions) countrywide, students expressed satisfaction with academic advising, and they placed academic advising among the three most encouraging factors in retention (Beal \& Noel, 1980). In contrast, Allen and Smith (2008) and Keup and Stolzenberg (2004) claim that students have expressed dissatisfaction with academic advising. However, the other researchers prove that academic advising is significant to student success, learning outcomes, and retention (Pascarella \&

Terenzini, 1980; Tinto, 1998; Hunter, McCalla-Wriggins, \& White, 2007). Given that many HEls may develop and maintain effective advising services that enable them to promote student satisfaction and increase retention.

Undoubtedly, academic advising has been playing an irreplaceable role in student achievement and accomplishment in the U.S. although commonly the ratio of academic advisor to student remains not high (Brock, 2010). Vianden and Barlow (2015) assert that when student and adviser have a strong connection with each other, it may result in positive student outcomes. For this and aforementioned reasons, Bailey et al. (2015) state colleges and universities should reevaluate their academic advising services and offer programs and advising assistance that could decrease the advisor-student ratio and enforce advisors to afford more comprehensive support for students. Redesigned academic programs, services, and academic advisor assistance may enforce student success, retention, and completion.

\subsubsection{Need for Better Transition into Higher Education in Azerbaijan}

In contrast to the U.S., the higher education system in Azerbaijan is centralized, the organizational structure is highly hierarchical, and the educational leadership executed is traditionally based on the top-down authority (Boer et al., 2017). Additionally, the four-year higher education institutions (HEls) do not provide undergraduate students, including transfer and first-year students, with academic advising that may assist in designing meaningful personal, social, and educational goals and foster student's whole growth and development. Consequently, when Light (2001) highlights the importance of advising and the same time its underestimation as a vital higher education experience, it resonates with the situation in the higher education system in Azerbaijan, which has not been utilizing this practice.

As academic advising services have not been embedded in HEls' culture in the country, I assume the 
administration of HEls are even not aware of the importance of academic advising services. Lack of awareness has resulted in missing efforts to embed this pivotal component in the education entities' culture. In fact, faculty advisors are currently appointed only to students who pursue a Master' s or PhD degree. Ultimately, academic advising that is conducted in HEls is fragmented and such mediocrity still exists.

Besides, students do not have the opportunity to benefit from prior academic support at high school, either. Although officially every school should have one psychologist at best, in most schools either the vacancy is not occupied, or a non-professional staff member performs this role. Because of this deficiency, students admitted in HEls on the basis of a centralized admission examination, and who are currently transitioning into HE, are not supported with any academic advisors' assistance and academic advising services.

\subsubsection{Need to Institute Academic Advising Services in Azerbaijan}

I believe academic advising as a social structure should be recommended to the Ministry of Education (MoE) so that the practice can be established in HEls. Furthermore, this recommendation may align with the goals of education reform initiatives in the Republic of Azerbaijan launched on the presidential decrees for the last 18 years. In Azerbaijan, students oftentimes struggle in the first and second semesters of higher education because there is not adequate academic support. Newly enrolled students are not ready for the space and community; they do not know where to get support or help of any kind. Instruction alone cannot help these students grow in the ways that will foster their achievements.

In Azerbaijan, applicants who receive the relevant state certificate on secondary, vocational or higher education are eligible to be admitted to HEls based on the results of the admission examination conducted by the State Examination Center (SEC) of the Republic of Azerbaijan. According to the independent education expert Asadov, currently, 51 state and nonstate universities serve more than 167.677 students, of which 70 percent are studying at their own expense and placed in the self-paying seats. Although the average tuition fee for a major for one academic year is 2,000AZN (\$1177), the most popular and favored majors cost 6500 (\$3824), 5000 (\$2941), 4300 (\$2529) AZN (Asadov, 2018). The education expert asserts that the tuition fees in local HEls are higher than that for many universities and colleges around the world while the quality of education is much lower. High tuition fees and low quality of education remain as the most compelling problems that possibly generate student drop out and transfer in Azerbaijan (Asadov, 2018).

In the recent past, to change major or type of education (from higher to vocational) was a hard task, and still it remains challenging. The only authority in the country is the Ministry of Education (MoE), and it is tasked to transfer both domestic students that studied abroad and domestic students who studied in local HEls to various higher education entities across the country. The students who studied at colleges and universities that are not accredited in foreign countries are not allowed to be transferred to HEls in Azerbaijan (Valekhov, 2017). I searched for hard data in the released 2016 Annual Report from Ministry of Education in Azerbaijan and the other relevant reports from MoE. The reports were vague in their descriptions of various points of data, and there was not any information on dropouts and transfer students. I also sent a letter and officially requested the State Exam Center (SEC) to report on any available data related to those students. SEC did not present any data on dropouts and transfer students and justified that recording that kind of data was not under SEC's purview.

According to the State Statistical Committee of Azerbaijan Republic (SSC, 2019), in the year 2016, 36126 students were admitted to the state and non-state universities based on the results of the admission examination conducted by SEC and 31138 students graduated with a Bachelor's degree from HEls across the country. Likewise, SSC did not report any data on dropouts and transfer students. However, the head of department for work with NGOS (nongovernmental organizations) and the media of MoE, Valekhov (2017) reports that in 2016 via the online application submission platform, which was launched in the same year (www.transfer.edu.az), 233 students were transferred to various HEls, including students who were studying abroad and only 46 students transferred to vocational schools because of poor academic performance (Valekhov, 2017). According to another department chair of MoE Aliyev (2019), via that online application submission platform all in all 1484 students were transferred to other HEls since the portal started to function in 2016. He also underlines that 805 students from local HEls and 21 students who were studying abroad used the portal and transferred to the local universities. Only four students with Master's Degree submitted their application to the portal for transfer. In addition, 107 students from the secondary vocational institution or specialty submitted their applications to the portal so that they could transfer to other secondary special education institutions across the country (Aliyev, 2019). The reality is that not all students, particularly firstyear students, are informed about the online submission platform. They are not necessarily aware of any other possibilities or ways to solve the problems they encounter because of a missing academic advising structure in an education entity in which they study. 
Universities, colleges, or vocational schools do not provide any academic advising services to direct those students to resources and guide them so that they can succeed. Missing academic advising structure may create a number of problems, including student transfer, dropout, and even expelling from the HEls in Azerbaijan. Additionally, I assume even when many students in HEls in Azerbaijan attain a degree, they are often not well-prepared and able to succeed in their careers or be engaged in citizenship.

Speaking about the demand in the labor market for the graduates from HEls in our country, the education expert Asadov emphasizes that the quality of education in colleges and training in specialized secondary schools is not at a high level. The expert clearly emphasizes that the key indicators of university graduates are low, and colleagues do not meet the requirements of the labor market. Therefore, the university graduates' employment rate is low in the country. Accessibility and content knowledge in HEls of the country needs to be reformed to expand the scope. There are many technical specialties that provide staff training, and it would be more appropriate to implement them in their facilities (Asadov, 2019).

I argue that this problem needs to be attended to by the MoE as there is a need for the establishment of academic advising services, and especially for training academic advisors to ensure that students can smoothly transition into $\mathrm{HE}$, easily navigate through the university structures, and gain clarity of expectations to achieve academic, personal, and career goals. As a result, more students will be likely to successfully graduate with achieved educational and career goals.

Academic advising structure and practice will also contribute to the sustainability of capacity-building in HEls. The HEls will ensure that graduates achieve efficient and necessary skills set that will assist them to succeed in their future career lives. There will be professional development and peer-learning opportunities for all stakeholders within the HEls that will develop new lines of communication, opportunities for networking and leadership development. HEls may create new organizational plans or they may assess and reexamine the old ones. HEls will collaborate with other non-profit partners in- and out of state, and this collaboration may increase and develop new sources of support.

\subsubsection{Purpose of the Study}

The overarching aim of this qualitative study is to understand how U.S. institutions assist students in transitioning into higher education, navigating through the campus, attaining success, persisting in their disciplines, and getting a degree. The explicit purpose of the study is to better understand how the individual characteristics, knowledge, skills, competencies, and experiences (i.e., qualifications) of both academic advisors and administrators in student affairs and other academic services help diverse students, particularly transfer and first-year students, transition into HE and successfully navigate through the campus.

\subsubsection{Research Questions}

The following three explicit research questions guided this study.

1. How is academic advising organized in a four-year public institution?

2. What structures, procedures, strategies, practices, resources and instruments, if any, do academic advisors and their supervisors utilize in supporting the first-year students in making a smooth transition into higher education?

3. What qualifications and skills do academic advisers and their supervisors perceive they have that allow them to help students succeed in higher education?

\section{LITERATURE REVIEW}

To create, share, and improve knowledge, students need to collaborate so that social and cognitive processes such as perception, learning, reflection, and reasoning occur simultaneously. These processes justify knowledge creation, knowledge sharing, and improve the acquired knowledge (Nonaka, 1994). Higher Education (HE) is considered one of the sources that constantly creates knowledge. The knowledge created and widely distributed drives economic growth and improves the world's countries' socioeconomic conditions (Davenport, 2001; Salvioni, Franzoni, \& Cassano, 2017). Given that, the knowledge economy based on HE becomes prosperous and remains sustainable (Dill \& Van Vught, 2010; Walton, 2011). Indisputably, HE grants both innovation and human capital growth through knowledge creation.

Given the importance of knowledge, transfer students and freshmen need assistance and support to be able not only to create, share, and improve their knowledge during their time in higher education institutions (HEls), but they should also acquire skills and grow a whole potential in order to navigate, persist, and achieve academic success to earn a degree (Handel \& Strempel, 2016; Herrera \& Jain, 2013; Grites, 2013; Laanan, Starobin, \& Eggleston, 2010; MacGeorge, Samter, \& Gillihan, 2005; DeBerard et al., 2004; Peach, 
2005). HEls in the U.S. provide students with support through established academic advising services and student affairs structures. Research advocates that academic advising services and student affairs positively contribute to student learning and success (Tinto, 1993; Hill et al., 2003). These services improve the quality of teaching and learning and help meet students' constantly growing and diversifying needs. Academic advising services and student affairs assist students in tightly connecting to an education entity and the community and becoming academically, emotionally, and socially satisfied, secured, and confident. Consequently, students are less likely to fail and more likely to gain various experiences to succeed (Hill et al., 2003; Mclnnis, 2004; Tinto, 1993).

Herewith, transition into higher education $(\mathrm{HE})$ remains as one of the most challenging stages for students in their adulthood in the U.S.A. (Arnett, 2006; Aseltine \& Gore, 2005; Cleveland et al., 2012; Huynh \& Fuligni, 2012; Liberman et al, 2014; Staff et al., 2010). HE provides opportunity and to realize this opportunity, colleges and universities strive to make access affordable for students. Once students obtain access to higher education one of the requirements for them is to gain appropriate knowledge. In addition, students should acquire adequate competencies and develop additional skills. Newly gained knowledge, competencies, and skills help them navigate, interact, collaborate, and develop credentials for successful graduation. Considering the challenging social and academic aspects of $\mathrm{HE}$, transition into HE needs to be perceivable and functional. Students need to be directed to useful resources and obtain valuable information and be able to adequately utilize them for academic success. Moreover, the resources should be available, and the information should also be easily utilized, as both enable students to effectively navigate through established systems, structures, and processes in an education entity (Tinto (1993) as cited in Bigger, 2005).

A few researchers critique Tinto's conceptual model, arguing that it does not translate well to the freshmen experience in HE. McCubbin (2003) highlights three criticisms with Tinto's model and considers the model "an inadequate model of student attrition". The author asserts the model does "not generalize beyond traditional students" and "academic integration is not an important predictor of student attrition" (McCubbin, 2003, p.1). According to Grites and Gordon (2000), students vary because of their "motivations, values, abilities, and other personal characteristics" (p. 120). Taking into consideration various levels of student motivation, recognizing transfer students and freshmen's values, assessing their abilities, and respecting their personal characteristics, HEls need to contribute to a student's knowledge construction (Brennan \& Teichler, 2008). The transfer students and freshmen should be exposed to the innovations to increase their social capital in the form of gained knowledge, adequate competencies, and additional skills development.

Diverse students transition into higher education in the United States public universities, and they encounter various challenges in their freshman year (MacGeorge, Samter, \& Gillihan, 2005; DeBerard et al., 2004; Peach, 2005). Yet, as Jackson (2010) advocates, "for most of them the change from a familiar environment into an unfamiliar one represents a period of disequilibrium" (p.341). Access to an education entity should be predictable as transfer students and freshmen differ due to their level of understanding of proceedings and academic requirements (Renn \& Reason, 2012). The academic language of the materials, tutorials, manuals, and the technology may sound unfamiliar. Students need predictable and accessible assistance and support to be able to understand and fulfill admission and academic requirements (e.g., to fill out special forms, submit documents, accomplish assignments, etc.) (McDonough (2004) as cited in Renn \& Reason, 2012 , p. 34). In this sense, first-year seminars, orientation programs, and summer bridge programs yield positive results and augment student persistence (Barefoot (2000); Barefoot (2005); Pascarella \& Terenzini (2005) as cited in Renn \& Reason, 2012, p. 67-69).

\subsection{Academic Advising and Advisors' Job Responsibilities}

In the U.S.A., academic advising as a common practice is utilized in higher education institutions (HEls) (Gordon et al., 2008; Kuhn, 2008). The research reveals that student retention, persistence, and progression to a degree depend on the effectiveness of academic advising and academic advisors' performance (Campbell \& Nutt, 2008; Hale, Graham, \& Johnson, 2009; Habley, 1981; Kuh, 2008; McArthur, 2005; Tinto,1999). Scholars assert that advising is a process while the others focus on the profession itself and mainly highlight the importance of social and academic support that academic advisors provide. As a profession, academic advising is evolving, and academic advisors have to meet diverse student body's constantly changing needs (Reinarz, 2000).

In the Concept of Academic Advising, which comprises three fundamental pillars - pedagogy, curriculum, and learning outcomes (National Academic Advising Association [NACADA], 2006), the preamble states, "Academic advising is integral to fulfilling the teaching and learning mission of higher education" (Gordon, Habley, \& Grites, 2008, p. 523). Academic advisors continue to impact students' academic, personal, social, and career development. Given the continuous impact of academic advising as a major contributing factor, colleges and universities use this workforce to direct students about academic, social, and personal issues 
(Harding, 2008; Kuhn, 2008).

Researchers believe that if academic advising service is well structured on a campus, it enables productive interaction of the academic advisors and students. Milem, Berger, and Dey (2000) state that it is an academic advisor's responsibility to provide students support outside the classroom. In addition, Light (2001) states, "good advising can have a profound impact" (p.15) on both the students and the whole campus. Supporting the previous scholars, Lowenstein (2006) asserts that likewise, teachers teach courses to provide students with their entire education, advisors assist students in experiencing the curriculum as a whole that enhances their academic learning (2006). Thus, academic advisors are responsible for guiding students to the resources and available services on campus and encouraging them to obtain appropriate information (Noel- Levitz, 1997; King, 1993). They should reach out to students and not miss a single opportunity to timely and properly advise the students who need their assistance and support, which means academic advisors enable students to acknowledge the structure and rationale for their entire education in HEls.

Huber and Miller (2013) share some insights on the results of the academic advisor's job responsibilities based on a NACADA survey conducted countrywide among the 2- and 4- year institutions in the U.S. in 2011. The survey results highlight the six most important responsibilities of the academic advisor. They can differ because of size and type of the education entities. As in the past, the academic advisor is responsible for course scheduling. The authors assume that the result of the survey may enforce the academic advising services and student affairs at institutions to consider some changes in the academic advisors' responsibilities to accommodate the students' challenges in career planning. Given to the possible changes in the academic advisors' responsibilities, the academic advising involves extensive information on social and academic issues and career planning. Abel (1980) asserts in the past the academic advisor's role was to help the students choose courses and set a schedule, but currently the academic advising programs require the academic advisors to assist the students to develop their full potential.

\subsubsection{Qualifications for Advisors}

Given the growing respect for the profession of an academic advisor and the considerable need for academic advising, the NACADA Academic Advising Core Competencies Model (2017) has identified three main content domains: the conceptual domain that incorporates ideas and theories; the informational domain that includes knowledge; and the relational domain that comprises skills. The academic advisors should acknowledge, incorporate, and utilize three core competency areas in the advising process so that the universities recognize them as accountable for the profession (NACADA, 2017).

\subsubsection{Styles of Academic Advising and Models of Academic Advising Services}

Research claims that students retain and succeed if they receive the quality academic advising (Drake, Jordan, \& Miller, 2013; Drake, 2011; Smith \& Allen, 2006; Young-Jones, Burt, Dixon, \& Hawthorne, 2013; Zhao, Golde, \& McCormick, 2007) and if advisors utilize various types or styles (Bloom, Hutson, \& He, 2013; Grites, 2013; Varney, 2013). Students academically benefit and gain good experience if advisors develop appropriate relationships with them. Academic advisors may demonstrate various styles and may be grouped according to the types or approaches of academic advising they facilitate (Gordon et al., 2008).

Six theoretical approaches and/or styles are utilized in academic advising, such as Pragmatic Approach (Borgard,1981) Prescriptive Approach (Barron \& Powell, 2014; Crookston, 1972;1994), Developmental Approach (Appleby, 2001; Crookston, 1972;1994), Intrusive (Proactive) Approach (Varney, 2012), Appreciative Approach (Bloom et al., 2008; 2013, Dialogic (Colgan, 2017). Hence, academic advisors may choose any to create their own styles and a personal philosophy to provide students advising. Given the importance of variety, two perspectives in a real-world context may make academic advising effective, which is how students understand themselves from their own perspective and from the academic advisors' perspective (Creamer, 2000). The academic advisor's awareness of those perspectives is pivotal. When advisors apply theories, utilize techniques, and ask questions, they should align them with the students' needs and the institutional mission, goals and values. Besides, the academic advisors' awareness of the role of theories, techniques, and questions they ask may impact their personal philosophy, approaches, and personal styles. For these reasons, academic advisors should do their best to align three components: theories, tools, and evidence.

Pardee (2004) claims the effectiveness of an academic advising program depends on how it is structured within an education entity, whether the academic advising program is structured at the department level, at the college level, and at a campus or institutional level. Once such a framework is established, it is crucial to scrutinize allocated resources and to evaluate academic advising programs. The more effective academic advising services become, the more students may be retained. The researchers presume that if academic advising services are not well established and they do not fit to an institutional mission and students' and 
faculty's needs, they may fail to be effective and both the institution and its constituents may become unsatisfied (Gordon et al., 2008).

In this sense, to determine the right organizational structure for academic advising is important (Gordon et al., 2008). When the chosen academic advising model is well integrated and does not oppose an institution's mission and characteristics and effectively serve the constituents, the model is likely to succeed (Pardee, 2004). Miller (2012) emphasizes academic advising in the 21st Century may seem complicated and meaningless unless discussions about academic advising models yield answers to the questions of who we advise, who advises, where we deliver academic advising, and how we divide responsibilities.

Research has not decently considered the impact of advising structures in the institutions on student achievement, although it introduces different organizational models that are utilized in colleges and universities (Tuttle, 2000; Pardee, 2004; Kuhtmann, 2004). Habley (1983) indicated seven separate models (1983, 1987, 1993): 1. Faculty Only 2. Supplementary 3. Split 4. Dual 5. Total Intake 6. Satellite 7. SelfContained. Regarding the impact of advising structures, Pardee (2004) has grouped Habley's Seven Models of Academic Advising Services as centralized, decentralized, and shared.

The first organizational structure offered by Pardee (2004) incorporates one centralized academic or administrative unit that provides advising service for the students by professional and faculty advisers. The advising delivered in the Centralized Model is consistent, and the professionals who advise are well-trained, their job is highly appreciated, and they are regularly rewarded for the service. It consists of only the SelfContained Model suggested by Habley (Gordon et al., 2008). The Centralized Model remains one of the most popular models that is utilized in community colleges (King, 2008).

In contrast, Pardee's (2004) second organizational structure decentralizes the advising delivery and holds each academic department responsible for providing the students with the professional or faculty advisor's assistance. The Decentralized Model incorporates Habley's Faculty-Only and Satellite Models. Similar to the Shared Model, the Decentralized Model lacks coordination and supervision and the advising delivered remains inconsistent. The coordinators may not have much authority over the academic advising process and academic advisors. As a result, little coordination and authority may challenge their credibility and negatively impact the consistency and quality of the academic advising process (Gordon et al., 2008).

The third organizational structure Pardee (2004) suggests encompasses an advising center in a central advising unit and in each academic department with regard to the students' major programs. This dual overlapping advising practice may create misconception of advisors' roles and responsibilities. The misconception of advisors' roles and responsibilities may also challenge the credibility of the whole advising process because of lacking coordination or supervision. The Shared Model embeds Habley's total IntakeModel, Supplementary, Split, and Dual models (Gordon et al., 2008).

\section{METHODOLOGY}

The qualitative exploratory descriptive study (Denzin, Lincoln, 2011) was based on educational inquiry (Maxwell, 2013), and the study drew primarily on interviews (Kvale, 2006). The constructivist and interpretivist frameworks were interchangeably applied (Cortty, 1998; Guba \& Lincoln, 2005; Patton, 2002; Seale et al., 2007). The collected, analyzed, and interpreted data facilitated understanding of the organization and delivery of academic advising in a four-year public institution in the U.S. (Merriam, 2001). For identifying study participants, a purposeful sampling, particularly snowball sampling strategy, was utilized. The saturation applied in participant sampling helped to find distinct knowledgeable individuals. Finally, 12 academic advisors and 12 supervisors, from eight different colleges at DSU, including student affairs and student services across the campus were chosen. Each of participants was interviewed during an hour. Additionally, four academic advisors and two supervisors were observed during two Academic Orientation Programs in the summer of 2018, including three first-year seminars in two different colleges across campus. The document review on the academic advising association NACADA was conducted. Data triangulation assisted in drawing the evidence from multiple sources. The construct validity and reliability of findings were addressed and established.

\section{RESULTS}

The study found that the professional advisors and supervisors fulfilled the roles and responsibilities within the shared academic advising model (centralized and decentralized) at DSU campus, and those roles and responsibilities aligned in many ways. Both academic advisors and supervisors showed they were equally cognizant of the importance of knowledge, skills, and competencies they should possess and academic advising styles they should utilize when they advised students. The findings suggested the academic advisors and supervisors acknowledged they were experiencing the change of advising system at DSU, and 
there was a big shift in the structure to make academic advising delivery somewhat consistent and centrally coordinated or overseen across the campus. The study findings did not propose any specific ways to advise the first-year students, except New Student Orientation, which incorporated Academic Orientation Programs in fall, spring, and summer terms and first-year seminars that introduced students to social and academic life at campus and that was a beneficial support for the first-year students' transition and experience of doing small-group activities.

The study also revealed that academic advisors and supervisors' evaluation and assessment of advising delivery were not completely centralized or unified across DSU's campus. Human Resources required everybody, including faculty, academic specialists, and other staff in job classification, to be evaluated at least once a year. However, colleges, departments, and even units determined how to evaluate academic advisors and supervisors. The evaluation forms or templates differed from college to college, from department to department, and from unit to unit. It was generally conducted as an annual review, and once a year the academic advisors wrote reports on the goals, strengths and challenges, and the work done, but there were not real benchmarks. Hence, the rewarding component was incorporated into the assessment process. The rewarding was established in the form of an Outstanding Academic Advising Award for new and established academic advisors, a faculty advisor and an administrator a couple of years ago. There was a clear interest and preference for being rewarded for the work done. Although academic advisors and supervisors strongly believed that in the direct line, they were visible and valued, particularly some academic advisors were not sure whether their work was sufficiently valued by the upper level administration or not. In fact, there was a tendency to conduct centralized student surveys and analyze the data to be used as the base for changes by a taskforce, and the departments or units individually launched student surveys to measure student satisfaction on academic advisors' performance by the leadership. The leadership was also prone to align professional development activities, academic advising training programs, and delivery of advising with NACADA core competency areas.

Another major finding was a new structure with an Assistant Dean for University Advising office that was established under the Associate Provost for Undergraduate Education and Dean of Undergraduate Studies Office, and it was a big shift to make academic advising delivery somewhat consistent and centrally coordinated or overseen across campus. A few years ago, the organizational change happened even at the college level, in the College of IT, Technology, and Machinery. Loosely coordinated and decentralized advising practice in the college transitioned and moved under the Undergraduate Studies Office.

The findings suggested academic advisors and supervisors utilized some home grown and other technologies, instruments, or tools in delivering advising. The data also proposed the ways academic advisors and supervisors communicated among them and with students, and how they attended to those students' personal, social, and academic needs. The data collected on the communication of academic advisors' community suggested it was occurring at the campus level, college, department and even group levels, which was supported by a brand-new Advisor Portal. It was recently launched for fast, constant, and sustainable virtual interaction and communication across the campus community and promoting networking. Yet, not all academic advisors were using and benefiting from the new portal as it was supposed to be, clearly expressing that they preferred emailing, using listservs, and instant messaging. They needed some time to adjust to using the Advisor Portal. The findings also informed about the academic advisors and supervisors' access to the resources and usage of student information for advising.

\section{DISCUSSION}

Although the findings were generally compatible with the literature reviewed, there were several areas in which they differed from it. As Cook (2009) and Frost (2000) argued the newly enrolled students arrived at campus with the diverse needs, they required advanced services and an authentic approach. In this sense, at DSU, academic advising was the primary source of curricular and academic guidance, regardless of students chosen majors and academic advisors were the chief workforce who provided service within the frame of the programs, sharing insights and guidance on academic, social, and/or personal matters.

Each of eight colleges and two programs included in this study was different. There was not a real method right then at the university, and that was kind of an individual performance of each academic advisor and supervisor. Academic advising focused on all undergraduates without any special focus on the first-year students, except two-day Academic Orientation Programs and first-year seminars.

Supporting the claim higher education institutions should contribute to student's knowledge construction (Brennan \& Teichler, 2008), this study illustrated some specific strategies academic advisors and supervisors used to help students build an adequate knowledge base at DSU campus and those proceedings could assist students to have an easier transition into the university and reach the third stage of incorporation 
(Tinto, 1993). In regard to the three stages Tinto (1993) identified, academic advisors and supervisors at the colleges and programs included in this study focused more on transition and incorporation stages. The topic of separation did not come up very often. The two-day STEM Summer Orientation Session was obviously designated to the transition and partially incorporation stages as the advisor and four mentors-peer advisors attempted to build a friendly rapport and establish trust, so they could develop closer relationship with students later (Bloom et al., 2008; Covey, 2006; Frost, 2000).

Bloom et al. (2008) assert that integration of theory and practice enables appreciative advisors to perform their roles and responsibilities in various settings either one-on-one or in groups. Relatively, at colleges and programs included in this study, students were provided with group advising sessions that may have generated students' growth as a whole, and students could have reached their full potential. In terms of academic advising styles, Appleby (2001) claims prescriptive advisors do not help advisees "develop a sense of responsibility for their academic choices" (p.1.). Likewise, King (2005) emphasizes the importance of intensive attention to diverse students' concerns that academic advisors should comprehensively consider and provide students with relevant support. At DSU, academic advisors and supervisors generally placed a considerable importance on motivating students and helping them overcome challenges that inferred with their concerns and needs.

Kuhn (2008) highlights the importance of academic advising guidance and direction. The advisors and supervisors at DSU admitted they were not counselors, coaches, or mentors. Still, they acknowledged the vitality of providing accurate information about counseling and career service networks, the resource center for people with disabilities, and other available services on campus. All seemed supportive and involved in personalizing students' special needs and wants. According to Appleby (2008), "Advising is teaching" (p.85), at DSU, academic advisors engaged in teaching first-year seminars offered in the colleges with limited enrolment and residential ones, contributing to students' continual growth both advising and teaching them.

\section{CONCLUSION}

This research may empower academic advisors and supervisors to articulate their achievements, contributions, and future needs at DSU and make coordination and monitoring of academic advising delivery effective and accountable. Also, the newly developed centralized Academic Advising Model based on the Academic Advising Model utilized in DSU, may be embedded in HEls in Azerbaijan to best ensure the firstyear students have equal access to quality studies and academically support them and help students gain clarity of expectations and get ready to achieve academic, personal, and career goals.

\section{REFERENCE LIST}

Abel, J. (1980, March). Academic Advising: Goals and a Delivery System. Journal of College Student Personnel, 21(2), pp. 151-155.

Aliyev, Rashad. 2011. Azerbaijan: How Equitable is Access to Higher Education? Khazar Journal of Humanities and Social Sciences 14 (1), 20-37.

Aliyev, Elnur. (2019). Ministry: Taffakkur University was not accredited. Students will not be provided with diploma. Retrieved from http://aztehsil.com/news/3291-nazirlik-tfkkruniversiteti-akkreditasiyadankemdiyi-n-tlblr-diplom-verilmyck-msahb.html

Appleby, D. (2001, March). The teaching-advising connection. The Mentor: An Academic Advising Journal. Retrieved from https://dus.psu.edu/mentor/old/articles/appleby0.htm

Appleby, D. C. (2008). Advising as teaching and learning. In V. N. Gordon, W. R. Habley, and T. J. Grites, Academic advising: A comprehensive handbook (2nd edition) (chapter 6). San Francisco: JosseyBass. Allen, J. M., \& Smith, C. L. (2008). Importance of, responsibility for, and satisfaction with academic advising: A faculty perspective. Journal of College Student Development, 49(5), 397-411.

Allen, J. M., \& Smith, C. L. (2008). Importance of, responsibility for, and satisfaction with academic advising: A faculty perspective. Journal of College Student Development, 49(5), 397-411.

Arnett, J. J. (2006). The Psychology of Emerging Adulthood: What Is Known, and What Remains to Be Known? In J. J. Arnett \& J. L. Tanner (Eds.), Emerging adults in America: Coming of age in the 21st century (pp. 303-330). Washington, DC, US: American Psychological Association. 
Aseltine, R. H., Jr., \& Gore, S. (2005). Work, Postsecondary Education, and Psychosocial Functioning Following the Transition from High School. Journal of Adolescent Research, 20(6), 615-639. http://dx.doi.org/10.1177/0743558405279360

Bailey, T. R., Smith Jaggars, S., \& Jenkins, D. (2015). Redesigning America's community colleges. Cambridge, MA: Harvard University Press.

Beal, P. E., and Noel, Lee (1980). What Works in Student Retention. lowa City, IA: The American College Testing Program, pp. 43- 45. Retrieved from https://files.eric.ed.gov/fulltext/ED197635.pdf

Bigger, J.J. (2005). Improving the odds for freshman success. Retrieved from NACADA Clearinghouse of Academic Advising Resources Website: http://www.nacada.ksu.edu/Resources/Clearinghouse/ViewArticles/Advising-first-year-students.aspx

Bloom, J. L., Hutson, B. L., \& He, Y. (2008). The appreciative advising revolution. Champaign, IL: Stipes.

Bloom, J. L., \& He, Y. (2013). Theoretical reflection: Personal practical theory. Academic Advising Today, 36(1). Retrieved from http:// www.nacada.ksu.edu/Resources/AcademicAdvising-Today/ViewArticles/TheoreticalReflections-Personal-Practical-Theory.aspx

Bloom, J. L., Hutson, B. L., \& He, Y. (2013). Appreciative advising. In J. K. Drake, P. Jordan, \& M. A. Miller (Eds.), Academic advising approaches: Strategies that teach students to make the most of college (pp. 83- 100). San Francisco, CA: Jossey-Bass.

Boer, Harry De, File, J., Huisman, J., Seeber, M., Vukasovic, M., \& Westerheiden, Don F. (2017). Policy Analysis of Structural Reforms in Higher Education: Processes and Outcomes. Palgrave Macmillan.

Borgard, J.H., (1981). Toward a pragmatic philosophy of academic advising. NACADA Journal, 1. (1), 1-6. Retrieved from http://nacadajournal.org/doi/pdf/10.12930/0271-9517-29.1.43

Brock, T. (2010). Young Adults and Higher Education: Barriers and Breakthroughs to Success. The Future of Children, 20(1): 109-132. Retrieved from https://files.eric.ed.gov/fulltext/EJ883081.pdf

Campbell, S. M., \& Nutt, C. L. (2008). Academic advising in the new global century: Supporting student engagement and learning outcomes achievement. Peer Review, 10 (1), 4-7.

Cleveland, M.J., Lanza, S.T., Ray. A.E, Turrisi, R., \& Mallett K.A. (2012). Transitions in first-year college student drinking behaviors: does pre-college drinking moderate the effects of parent and peer-based intervention components? Psychology of Addictive Behaviors, 26, 440-450.

Cook, S. (2009). Important events in the development of academic advising in the United States. NACADA Journal, 29 (2), 18-40. Retrieved from http://www.nacadajournal.org/doi/pdf/10.12930/0271-951729.2.18

Colgan, L. A. (2017). Think About It: Philosophy and Dialogic Advising. NACADA Journal, 37 (1), pp. 66-73. Retrieved from http://www.nacadajournal.org/doi/pdf/10.12930/NACADA-15-045

Covey, S. M. R. (2006). The speed of trust. New York, NY: Free Press.

Creamer, D. G. (2000). Use of theory in academic advising. In Gordon, V.N. and Habley. W. R. Academic Advising: A Comprehensive handbook. San Francisco: Jossey-Bass.

Crookston, B. B. (1972). A developmental view of academic advising as teaching. Journal of College Student Personnel, 13, 12-17.

Crookston, B. B. (1994). A Developmental View of Academic Advising As Teaching. NACADA Journal: Fall, 14 (2), pp. 5-9. Retrieved from http://www.nacadajournal.org/doi/pdf/10.12930/0271-9517-14.2.5

Crotty, M. (1998). The foundations of social research: Meaning and perspective in the research process. London; Thousand Oaks, Calif.: Sage Publications.

Davenport, P. (2001). Universities and the Knowledge Economy. Ivey Business Journal., 64-73 Retrieved from https://iveybusinessjournal.com/publication/universities-and-the-knowledge-economy/

DeBerard, M. S., Spielmans, G. I., \& Julka, D C. (2004). Predictors of academic achievement and retention among college freshmen: A longitudinal study. College Student Journal, 38, pp. 66-80.

Denzin, N. K., \& Lincoln, Y. S. (2011). The SAGE Handbook of Qualitative Research. Thousand Oaks, CA: Sage. 
Dill, D. D. \& Van Vught, A. F. (2010). (Eds.). National Innovation and the Academic Research Enterprise: Public Policy in Global Perspective. Baltimore: Johns Hopkins University Press. 592 pages. ISBN-13: 9780801893742.

Drake, J. K. (2011). The role of academic advising in student retention and persistence. About Campus,16(3), 8-12. doi:10.1002/abc. 20062

Drake, J. K., Jordan, P., \& Miller, M. A. (Eds.)._(2013.) Academic advising approaches: Strategies_that teach students to make the most of college. San Francisco, CA: Jossey-Bass.

Frost, S. H. (2000). Historical and philosophical foundations for academic advising. In V. Gordon \& W. Habley (Eds.), Academic advising: A comprehensive handbook (pp. 3-17). San Francisco: JosseyBass.

Gordon, N. V., Habley, R. W., \& Grites, J.T. (2008, September). Academic Advising: A Comprehensive Handbook, (2nd ed.). Jossey-Bass, ISBN: 978-0-470-37170-1,608 pages.

Gordon, V. N., Habley, W. R., \& Grites, T. J. (Eds.). (2011). Academic advising: A comprehensive handbook. San Francisco, Cal: John Wiley \& Sons, Inc.

Grites, J. T. (1979). Academic Advising: Getting Us Through the Eighties, AAHE ERIC/Higher Education Research Report, Washington, D.C.: American Association for Higher Education Retrieved from https://files.eric.ed.gov/fulltext/ED178023.pdf

Grites, T. J. (2013). Successful transitions from two-year to four-year institutions. New Directions for Higher Education, 162, 61-68. doi:10.1002/he.20057

Grites, T. and Gordon, N.V. (2000). Developmental Academic Advising Revisited. NACADA Journal: Spring, 20 (10) pp. 12-15. Retrieved from http://www.nacadajournal.org/doi/pdf/10.1zxzz2930/0271-9517$\underline{20.1 .12}$

Habley, W. R. (1981). Academic advisement: The critical link in student retention. NASPA Journal, 18(4), 4549.

Habley. W. R. (1983). Organizational structures for academic advising: models and implications. Journal of' College Student Personnel, 21, 535-539.

Habley, W. R. \& McCauley, M. E. (1987). The relationship between institutional characteristics and the organization of advising services. NACADA Journal, 7(1), 27- 39.

Habley, W. (1993). The organization and effectiveness of academic advising in community colleges. In M. King (Ed.), New directions for community colleges, vol. 21 (pp. 33- 46). San Francisco: Jossey-Bass.

Hagen, P. L., \& Jordan, P. (2008). Theoretical foundations of academic advising. In V. N. Gordon, W. R. Habley, \& T. J. Grites (Eds.), Academic advising: A comprehensive handbook (2nd ed.) (pp. 17-35). San Francisco, CA: Jossey-Bass.

Hale, M. D., Graham, D. L., \& Johnson, D. M. (2009). Are students more satisfied with academic advising when there is congruence between current and preferred advising styles? College Student Journal, 43(2). pp. 313-324.

Handel, S. J. and Strempel, E. (2016). Transition and Transformation: Fostering Transfer Student Success.

Hemwall, M. K. \& Trachte, K. (2005). Academic advising as learning: 10 organizing principles. NACADA Journal, 25 (2), 74-83.

Hemwall, M. K., \& Trachte, K. C. (1999). Learning at the core: Toward a new understanding of academic advising. NACADA Journal, 19(1), 5-11.

Herrera, A., \& Jain, D. (2013). Building a transfer-receptive culture at four-year institutions. New Directions for Higher Education, 2013(162), 51-59. doi:10.1002/he.20056

Hill, C. E., Kellems, I. S., Kolchakian, M. R., Wonnell, T. L., Davis, T. L., \& Nakayama, E. Y. (2003). The therapist experience of being the target of hostile versus suspected-unasserted client anger: Factors associated with resolution. Psychotherapy Research, 13, 475- 491.

Huber, J. A. \& Miller, M. A. (2013). Implications for advisor job responsibilities at 2-and - 4 -year Institutions. Retrieved from NACADA Clearinghouse Resources. Web Site: http://www.nacada.ksu.edu/Resources/Clearinghouse/ViewArticles/Advisor-Job-Responsibilities$\underline{a 3045 . a s p x}$ 
Hunter, M. S., \& White, E. R. (2004). Could fixing academic advising fix higher education? About Campus, 9, 20-25.

Hunter, M. S., McCalla-Wriggins, B., \& White, E. R. (Eds.). (2007). Academic advising: New insights for teaching and learning in the first year (Monograph No. 46 [National Resource Center]; Monograph No. 14 [National Academic Advising Association]). Columbia, SC: University of South Carolina, National Resource Center for The First-Year Experience and Students in Transition.

Huynh, V.W. \& Fuligni, A.J. (2012). Perceived ethnic stigma across the transition to college. Journal of Youth and Adolescence, 41, 817-830.

Jackson, C. (2010). Transitions into Higher Education: Gendered implications for academic self-concept. Oxford Review of Education, 29 (3), pp 331-346 / Published online: 19 Aug 2010 https://www.tandfonline.com/doi/abs/10.1080/03054980307448

Keup, J. R., \& Stolzenberg, E. B. (2004). The 2003 our first college year (YFCY) survey: Exploring the academic and personal experiences of first-year students. Monograph \#40. Columbia, SC: University of South Carolina, National Resource Center for the First-Year Experience and Students in Transition.

King, M. C. (1993). Advising Models and Delivery Systems. New directions for community colleges (01943081), (82), p. 47.

Kuhn, T. L. (2008). Historical foundations of academic advising. In V. N. Gordon, W. R. Habley, \& T. J. Grites, (Eds.), Academic advising: A comprehensive handbook ( $2^{\text {nd }}$ ed.) (pp. 3-16). San Francisco, CA: Jossey Bass.

Kuhtmann, S. M. (2004). Mission impossible? Advising and institutional culture. NACADA Journal: Spring Fall, 24 (1-2), pp. 99-110. Retrieved from http://www.nacadajournal.org/doi/pdf/10.12930/0271-951724.1-2.99

Kvale, S. (2006). Dominance Through Interviews and Dialogues. Qualitative Inquiry, 12(3), 480500. https://doi.org/10.1177/1077800406286235

Laanan, F. S., Starobin, S. S., \& Eggleston, L. E. (2010). Adjustment of community college students at a four-year university: Role and relevance of transfer student capital for student retention. Journal of College Student Retention, 12(2), 175-209. doi:10.2190/CS.12.2.d

Liberman, A. M., Kirk, D. S., \& Kim, K. (2014). Labeling effects of first juvenile arrests: Secondary deviance and secondary sanctioning. Criminology, 52, 345- 370. doi:10.1111/1745-9125.12039

Light, R. (2001). Making the most of college: Students speak their minds. Cambridge, MA: Harvard University Press.

Lowenstein, M. (2005). If Advising is Teaching, What Do Advisors Teach?. NACADA Journal: Fall, Vol. 25, No. 2, pp. 65-73. Retrieved from http://www.nacadajournal.org/doi/pdf/10.12930/0271-9517-25.2.65

Lowenstein, M. (2006). A learning-centered view of teaching as advising. Proceedings from the Fifth Annual Professional Development Conference on Academic Advising. Retrieved from www.psu.edu/dus/mentor/proc01 $\mathrm{ml} . \mathrm{htm}$

Lowenstein, M. (2013). Envisioning the future. In J. K. Drake, P. Jordan, \& M. A. Miller (Eds.), Academic advising approaches: Strategies that teach students to make the most of college (pp. 243-258). San Francisco, CA: Jossey-Bass.

MacGeorge, E. L., Samter, W., \& Gillihan, S. J. (2005). Academic stress, supportive communication, and health. Communication Education, 54, pp. 365-372.

Maxwell, J. A. (2013) Qualitative Research Design: An interactive approach, 3rd edition. Thousand Oaks, CA: SAGE Publications.

McArthur, C. R. (2005 March). Faculty-Based Advising: An Important Factor in Community College Retention. Community College Review, 32 (4) pp. 1-18.

McCubbin, I. (2003). An examination of criticisms made of Tinto's 1975 student integration model of attrition. Glasgow: University of Glasgow. Retrieved from http://www.psy.gla.ac.uk/ steve/localed/icubb.pdf

McInnis, C. (2004). Studies of Student Life: an overview. European Journal of Education, 39 (4).

Merriam, S.B. (2001). Qualitative Research and Case Study Applications in Education, San Francisco: Jossey-Bass Publishers. 
Milem, J.F., Berger, J.B., \& Dey, E.L. (2000). Faculty time allocation. Journal of Higher Education 71(4), 454.

Miller, M.A. (2012). Structuring our conversations: Shifting to four dimensional advising models. In Carlstrom, A. \& Miller, M.A., 2011 national survey of academic advising. (Monograph No. 25.). Mantattan, KS: National Academic Advising Association. Retrieved from the NACADA Clearinghouse of Academic Advising Resources website http://www.nacada.ksu.edu/Resources/Clearinghouse/ViewArticles/Structuring-Our-Conversations-Shifting-to-Four-Dimensional-Advising-Models.aspx

NACADA: The Global Community for Academic Advising. (2006). NACADA concept of academic advising. Retrieved from NACADA Clearinghouse of Academic Advising Resources Web Site: http://www.nacada.ksu.edu/Resources/Clearinghouse/View-Articles/Concept-of-AcademicAdvising.aspx

NACADA. (2006). What is academic advising? Manhattan, KS: National Academic Advising Association.

NACADA: The Global Community for Academic Advising. (2017). NACADA academic advising core competencies model. Retrieved from https://www.nacada.ksu.edu/Resources/Pillars/CoreCompetencies.aspx

Noel, L., \& Levitz, R. (1997). Strategic advances in recruitment and retention. USAGROUP Noel-Levitz, Inc, lowa City, IA

Nonaka, I. (1994 February). A Dynamic Theory of Organizational Knowledge Creation Organization Science, 5 (1), pp. 14-37

O'Banion, T. (1972). An academic advising model. Junior College Journal, 42, 62-69.

O'Banion, T. (2013). Academic Advising: The Key to Student Success. Washington, DC: Community College Press, Rowman \& Littlefield Publishers, American Association Of Community Colleges

Pardee, C. F. (2004). Organizational structures for advising. The NACADA Clearinghouse of Academic Advising Resources. Retrieved from: http://www.nacada.ksu.edu/Resources/Clearinghouse/ViewArticles/Organizational-Models-for-Advising.aspx

Patton, Q. M. (2002). Qualitative Evaluation and Research Methods (3rd ed.). Newbury Park, CA: Sage Publication, Inc.

Peach, D. (2005). Ensuring student success - the role of support services in improving the quality of the student learning experience. Studies in Learning, Evaluation, Innovation, and Development, 2, pp.115.

Remler, D.K., \& Van Ryzin, G.G. (2015). Research Methods in Practice: Strategies for Description and Causation, (2nd ed.). SAGE Publications.

Renn, K. A., \& Reason, R. D. (2012). College students in the United States: Characteristics, experiences, and outcomes. San Francisco: Jossey-Bass.

Robbins, S., Allen, J., Casillas, A., Akamigbo, A., Saltonstall, M., Campbell, R., et al. (2009). Associations of resource and service utilization, risk level, and college outcomes. Research in Higher Education, $50(1)$, pp. $101-118$.

Saldaña, J. (2012). The coding manual for qualitative researchers (2nd ed.). Thousand Oaks, CA: Sage.

Saldaña, J. (2016). The coding manual for qualitative researchers (3rd ed.). Thousand Oaks, CA: SAGE Publications Inc.

Seidman, I. (2013). Interviewing as qualitative research: A guide researchers in education and the social sciences (4th ed.). New York, NY: Teachers College Press.

Seale, C., Gobo, G., Gubrium, J.F. and Silverman, D. (2007). Qualitative Research Practice., London: Sage.

Self, C. (2013). Implications of advising personnel of undergraduates 2011 National Survey. Retrieved from NACADA Clearinghouse of Academic Advising Resources Web Site:

http://www.nacada.ksu.edu/Resources/Clearinghouse/View-Articles/Implications-of-advisingpersonnel-of-undergraduates-2011-National-Survey.aspx

Smith, C. L., \& Allen, J. M. (2006). Essential functions of academic advising: What students want and get. NACADA Journal, 26(1), 56-66. doi: 10.12930/0271-9517-26.1.56 
Staff, J., Schulenberg, J.E., Maslowsky, J., Bachman, J.G., O'Malley, P.M., Maggs, J.L., \& Johnston, L, D. (2010). Substance use changes and social role transitions: proximal developmental effects on ongoing trajectories from late adolescence through early adulthood. Development and Psychopathology, 22, 917-932.

Tinto, V. (1993). Leaving College: Rethinking the Causes and Cures of Student Attrition (2nd ed.). Chicago: University of Chicago Press.

Tinto, V. (1998). "Colleges as Communities: Taking Research on Student Persistence Seriously." Review of Higher Education. 21,2 (Winter):167-78.

Tinto, V. (1999) Taking Retention Seriously: Rethinking the First Year of College. NACADA Journal: Fall, 19 (2), pp. 5-9. Retrieved from http://www.nacadajournal.org/doi/pdf/10.12930/0271-9517-19.2.5

Tinto, V. (2006). Research and practice of student retention: What's next? Journal of College Student Retention: Research, Theory \& Practice, 8(1), 1-19. doi:10.2190/4YNU-4TMB22DJ-AN4W. Retrieved from http://citeseerx.ist.psu.edu/viewdoc/download?doi=10.1.1.133.2661\&rep=rep1\&type=pdf

Tuttle, K. N. (2000). Academic advising. New Directions for Higher Education, 111, 15- 25.

Turtle, K. N. (2000). Academic advising. In L. K. Johnsrud \& V. J. Rosser (Eds.), Understanding the work and career paths of midlevel administrators. San Francisco: Jossey-Bass.

Valekhov, G. (2017, July 14). Ministry of Education clarified transfer students' case. Nauka. Retrieved from https://ru.sputnik.az/science/20170714/411107953/azerbaijan-minobrazovaniya-studenti-perevodvuz.html

Varney, J. (2012, September). Proactive (intrusive) advising! Academic Advising Today, 35(3). Retrieved from http://www.nacada.ksu.edu/Resources/Academic-Advising-Today/View-Articles/ProactiveIntrusive-Advising.aspx

Varney, J. (2013). Proactive advising. In J. K. Drake, P. Jordan, \& M. A. Miller (Eds.), Academic Advising Approaches: strategies that teach students to make the most of college. San Francisco, CA: Jossey-

Young-Jones, A. D., Burt, T. D., Dixon, S., \& Hawthorne, M. J. (2013). Academic advising: Does it really impact student success? Quality Assurance in Education, 21(1), 7-19. doi:10.1108/ 09684881311293034

Zhao, Chun-Mei, Chris M. Golde \& Alexander C. McCormick (2007) More than a signature: how advisor choice and advisor behaviour affect doctoral student satisfaction, Journal of Further and Higher Education, 31:3, 263-281, DOI: $\underline{10.1080 / 03098770701424983}$ 